\title{
Kajian Peluang Kerjasama Pemerintah Swasta (Kps) Dalam Penyediaan Infrastruktur Di Pelabuhan Tanjung Emas Semarang
}

\author{
Desy Yuli Aryani', Mardwi Rahdriawan²
}

Diterima : 30 September 2015

Disetujui : 31 Desember 2015

\begin{abstract}
Port infrastructure in the transport system is a valuable asset for the national economy in order to face the globalization of free trade. Problems of provision of port infrastructure constraints in general is a factor financing. One of the government's efforts to overcome the problems in the provision of infrastructure financing is through the Public Private Partnership (PPP). This research was conducted in order to determine the opportunities and constraints of PPP implementation in the provision of port infrastructure by Master Plan Tanjung Emas Semarang. This study used a qualitative approach with a qualitative descriptive analysis techniques conducted on the characteristics of the PPP, the perception of government and stakeholders, as well as regulatory and institutional policies related to the implementation of the PPP. From this research it is known that in the construction and development of the port of Tanjung Emas does not currently use the PPP scheme because of the ownership status of Tanjung Emas port assets that are still in data collection, and a lack of understanding of the parties implementing the PPP. But the chances of implementing a PPP scheme is still possible in the area of ownership of assets remain below the government.
\end{abstract}

Keyword: opportunities, constrains, PPP, infrastructure, port

\begin{abstract}
ABSTRAK
Infrastruktur pelabuhan dalam sistem transportasi merupakan aset berharga bagi perekonomian nasional dalam rangka menghadapi globalisasi perdagangan bebas. Kendala permasalahan penyediaan infrastruktur pelabuhan pada umumnya adalah faktor pembiayaan. Salah satu upaya pemerintah untuk mengatasi permasalahan pembiayaan dalam penyediaan infrastruktur adalah melalui program Kerjasama Pemerintah Swasta (KPS). Penelitian ini dilakukan dengan tujuan untuk mengetahui peluang dan kendala pelaksanaan KPS dalam penyediaan infrastruktur pelabuhan berdasarkan Rencana Induk Pelabuhan Tanjung Emas Semarang. Penelitian ini menggunakan pendekatan kualitatif dengan teknik analisis deskriptif kualitatif yang dilakukan terhadap karakteristik KPS, persepsi pemerintah dan stakeholder, serta peraturan dan kebijakan kelembagaan terkait pelaksanaan KPS. Dari hasil penelitian tersebut diketahui bahwa dalam pembangunan dan pengembangan pelabuhan Tanjung Emas pada saat ini tidak menggunakan skema KPS dikarenakan status kepemilikan aset pelabuhan Tanjung Emas yang masih dalam pendataan, dan kurangnya pemahaman pihak-pihak pelaksana KPS. Namun peluang penerapan skema KPS masih mungkin dilakukan pada kawasan yang status kepemilikan asetnya masih berada dibawah pemerintah.
\end{abstract}

Kata Kunci: peluang, kendala, KPS, infrastruktur, pelabuhan

\footnotetext{
1 Pusat PSDM Perhubungan Laut

Kontak penulis: deltasierra_39@yahoo.com

2 Dosen Magister Pembangunan Wilayahdan Kota, Undip Semarang, Jawa Tengah
} 
Aryani | Kajian Peluang Kerjasama Pemerintah Swasta (Kps) Dalam Penyediaan Infrastruktur Di Pelabuhan Tanjung

Emas Semarang

JPWK 11 (4)

\section{PENDAHULUAN}

Pelabuhan merupakan pintu gerbang arus keluar masuk perdagangan. Pelabuhan juga disebut sebagai simpul dari mata rantai kelancaran muatan angkutan laut dan darat. Jinca (2011) mengatakan bahwa peranan penting yang diemban oleh pelabuhan sesuai fungsinya memerlukan penguatan operasional. Ketersediaan infrastruktur penunjang aktivitas pelabuhan yang memadai akan mempercepat pertumbuhan ekonomi daerah dan pembangunan nasional. Infrastruktur pelabuhan dalam suatu sistem transportasi merupakan sarana untuk memfasilitasi perdagangan eksternal suatu negara. Investasi pelabuhan merupakan aset berharga bagi perekonomian nasional dalam rangka menghadapi globalisasi perdagangan bebas. Berdasarkan berbagai kajian, Saleh et al (2014:14) menyimpulkan penyebab permasalahan infrastruktur secara umum antara lain adalah faktor kelangkaan pembiayaan, ketidakjelasan kewenangan dan tanggung jawab, ketidaksiapan kelembagaan dan peraturan pendukung, ataupun permasalahan resiko pembangunan infrastruktur.

Dalam Rencana Tata Ruang Wilayah (RTRW) Provinsi Jawa Tengah, pelabuhan Tanjung Emas Semarang merupakan kawasan stategis yang termasuk dalam kawasan khusus BWK III sebagai pelabuhan utama yang sangat berperan dalam perkembangan dan pertumbuhan ekonomi Jawa Tengah. Pembangunan dan pengembangan kawasan pelabuhan Tanjung Emas merupakan salah satu upaya pemerintah dalam menata infrastruktur pelabuhan yang tersedia saat ini. Pembangunan dan pengembangan pelabuhan Tanjung Emas telah ditetapkan pemerintah dengan Peraturan Menteri Perhubungan Nomor PM.18 Tahun 2013 tentang Rencana Induk Pelabuhan Tanjung Emas Semarang. Secara konseptual di dalam peraturan tersebut telah disebutkan bahwa untuk menyelenggarakan kegiatan kepelabuhanan yang meliputi pelayanan jasa, kegiatan ekonomi dan pemerintahan dibutuhkan areal daratan seluas 963,925 Ha dan areal perairan seluas $17.800 \mathrm{Ha}$.

Pengembangan sarana dan prasarana transportasi laut terutamanya infrastruktur pelabuhan berkelanjutan melibatkan banyak pihak yang mungkin memiliki persepsi yang berbeda-beda, sehingga diperlukan langkah strategis dan perubahan kebiijakan dalam mendukung pengembangan dan pembangunan infrastruktur pelabuhan. Salah satu upaya yang dilakukan pemerintah untuk mengatasi permasalahan pembiayaan dalam penyediaan infrastruktur pelabuhan adalah dengan melaksanakan program Kerjasama Pemerintah Swasta (KPS) atau Public Private Partnerships (PPP). Skema KPS merupakan bagian penting dalam pembangunan infrastruktur berbagai bidang. Berawi dan Susantono (2012) mengemukakan bahwa pihak-pihak yang termasuk dalam KPS dibagi menjadi 3 (tiga) kategori yaitu sektor pemerintah, sektor swasta dan sektor komunitas masyarakat. Kesuksesan KPS pada pembangunan infrastruktur erat kaitannya dengan peningkatan efisiensi dan produktivitas, penciptaan manfaat lebih (value for money), inovasi serta realisasi investasi swasta (Koppenjan, 2008 dalam Berawi dan Susantono, 2012). Namun selama ini pelaksanaan KPS dalam mendukung pertumbuhan infrastruktur masih belum dapat dioptimalkan.

Sebagai sebuah sistem yang masih berkembang, dinamika tersebut tentu harus dipahami sebagai sebuah tantangan yang perlu diketahui, maka pertanyaan yang dikaji dalam penelitian ini adalah: Bagaimana peluang Kerjasama Pemerintah Swasta (KPS) dalam penyediaan infrastruktur pelabuhan Tanjung Emas Semarang? 
JPWK 11 (4)

Di Pelabuhan Tanjung Emas Semarang

\section{METODE PENELITIAN}

Penelitian yang dilakukan ini merupakan penelitian terapan kualitatif (qualitative applied research). Dawson (2002:14) berpendapat bahwa penelitian kualitatif dilakukan dengan menggali sikap, tingkah laku dan pengalaman melalui beberapa metode. Hal ini merupakan usaha untuk memperoleh opini yang lebih mendalam dari partisipan. Oleh karena itu dalam penelitian ini digunakan pendekatan kualitatif, dengan didasarkan pada pertimbangan bahwa dalam pemahaman diperlukan informasi detail untuk menemukan jawaban atas pertanyaan penelitian.

Dalam penelitian ini metode pengumpulan data dilakukan dengan observasi terhadap kondisi infrastruktur di kawasan pelabuhan Tanjung Emas, wawancara dan telaahan dokumen seperti dokumen RTRW, Rencana Induk Pelabuhan dan peraturan penyelenggaraan kegiatan pelabuhan. Sampling yang digunakan adalah teknik purposive sampling dengan key person yang terdiri dari Kementerian Perhubungan Direktorat Jenderal Perhubungan Laut sebagai pihak pemerintah, dan Kantor Kesyahbandaran dan Otoritas Pelabuhan (KSOP) Kelas I Tanjung Emas serta PT. Pelabuhan Indonesia III (Persero) sebagai stakeholder di pelabuhan Tanjung Emas Semarang.

\section{GAMBARAN UMUM WILAYAH PENELITIAN}

Pelabuhan Tanjung Emas terletak di pantai utara Jawa Tengah dengan posisi $06^{\circ} 53^{\prime} 00^{\prime \prime}$ LS - $06^{\circ}$ 57' 00" LS dan $110^{\circ} 24^{\prime}$ o0" BT - $110^{\circ} 26^{\prime}$ 02" BT. Pelabuhan Tanjung Emas ini terletak di bagian utara Kota Semarang. Pelabuhan Tanjung Emas memiliki daerah ingkungan kerja perairan seluas $1.700 \mathrm{Ha}$ dan daerah lingkungan kerja daratan seluas $636 \mathrm{Ha}$. Dalam daerah lingkungan kerja tersebut, pelabuhan Tanjung Emas memiliki fasilitas yang berfungsi untuk menunjang aktivitas pelabuhan. Fasilitas tersebut meliputi fasilitas pelayanan kapal, alur, dermaga/tambatan, pergudangan maupun lapangan penumpukan, terminal penumpang, terminal peti kemas, listrik serta air bersih.

Sumber: Google earth, 2015

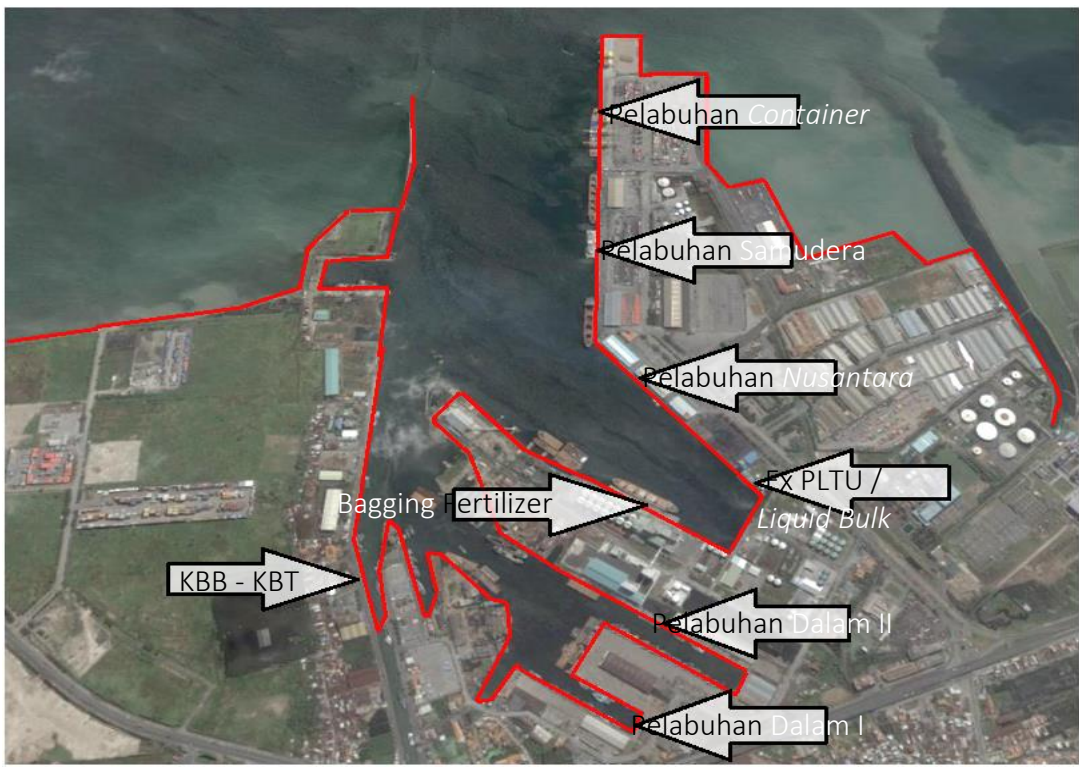

GAMBAR 1.1

FASILITAS PELABUHAN TANJUNG EMAS SEMARANG 
Aryani | Kajian Peluang Kerjasama Pemerintah Swasta (Kps) Dalam Penyediaan Infrastruktur Di Pelabuhan Tanjung

Emas Semarang

JPWK 11 (4)

Terminal Peti Kemas Semarang (TPKS) dibentuk sejak 1 Juli 2001 (sesuai Keputusan Direksi PT. Pelabuhan Indonesia III (Persero) Nomor : KEP.46 / RP.1.08 / P.III-2001 tanggal 29 Juni 2001 menjadi Terminal Operator Pelayanan Jasa Handling Container International. Terhitung tanggal 1 Juli 2001 Terminal Peti Kemas Semarang dikelola oleh PT. Pelabuhan Indonesia III Cabang Terminal Peti Kemas Semarang setara dengan PT. Pelindo III (Persero) Cabang Tanjung Emas Semarang. TPKS terletak di lokasi strategis ditengah-tengah pulau Jawa yang memberikan pelayanan jasa peti kemas (container terminal handling) yang handal, aman, dan terintegrasi antar moda serta didukung dengan penggunaan teknologi informasi yang modern dan di desain untuk memenuhi kebutuhan pengguna jasa angkutan peti kemas.

TPKS memiliki wilayah area kerja dengan luas 29,2 Ha dan panjang dermaga $495 \mathrm{~m}$ yang akan diperpanjang $105 \mathrm{~m}$ dan lebar dermaga $25 \mathrm{~m}$. Tata letak terminal peti kemas terdiri atas lapangan penumpukan peti kemas, area parkir chasis serta maintenance shop.

\section{KAJIAN TEORI}

Grigg (1988) infrastruktur merupakan sistem fisik yang menyediakan transportasi, irigasi, drainase, bangunan gedung dan fasilitas publik lainnya, yang dibutuhkan untuk memenuhi kebutuhan dasar manusia baik kebutuhan sosial maupun kebutuhan ekonomi. Infrastruktur sebagai pendukung utama sistem sosial dan sistem ekonomi dilaksanakan dalam konteks keterpaduan dan menyeluruh (Kodoatie, 2005). Sedangkan Perpres Nomor 38 Tahun 2015 tentang Kerjasama Pemerintah Dengan Badan Usaha Dalam Penyediaan Infrastruktur memberikan definisi bahwa infrastruktur adalah fasilitas teknis, fisik, sistem, perangkat keras dan lunak yang diperlukan untuk melakukan pelayanan kepada masyarakat dan mendukung jaringan struktur agar pertumbuhan ekonomi dan sosial masyarakat dapat berjalan dengan baik. Penyediaan infrastruktur merupakan kegiatan yang meliputi pekerjaan konstruksi untuk membangun atau meningkatkan kemampuan infrastruktur dan/atau kegiatan pengelolaan infrastruktur dan/atau pemeliharaan infrastruktur dalam rangka meningkatkan kemanfaatan infrastruktur.

The National Council For Public Private Partnerships (NCPPP) diakses dari www.ncppp.org, mendefinisikan KPS adalah sebuah perjanjian kontrak (contractual) antara pemerintah dengan pihak swasta. Sedangkan menurut Bult-Spiering and Dewulf (2006) dalam Berawi dan Susantono (2012) definisi KPS adalah:

a. KPS merupakan reformasi manajemen ketika fungsi pemerintahan dan birokrasi mengalami perubahan dan pencerahan dari interaksinya dengan manajemen profesional yang biasanya dimiliki oleh sektor swasta.

b. KPS adalah kerjasama yang melembaga dari sektor publik dan sektor swasta yang bekerja bersama untuk mencapai target tertentu ketika kedua belah pihak menerima resiko investasi atas dasar pembagian keuntungan dan biaya yang dipikulnya.

c. KPS adalah kerjasama antara pemerintah dan swasta yang menghasilkan produk atau jasa dengan resiko, biaya, dan keuntungan ditanggung bersama berdasarkan nilai tambah yang diciptakannya.

Menurut Grimsey dan Lewis (2004), secara umum karakteristik KPS meliputi: peserta (participants), hubungan (relationship), sumber daya (resourcing), komitmen untuk berbagi (sharing) dan keberlanjutan/kontinuitas (continuity). Sedangkan karateristik khusus KPS terdiri atas: jenis kerjasama (type), fokus pada pelayanan (focus on service), siklus pembiayaan (wholeof-life cycle costing), inovasi (innovation) dan alokasi resiko (risk allocation). 
Berdasarkan kajian yang dilakukan oleh Pusat Kajian Strategis Pelayanan Jasa Perhubungan (PKSPJP) Departemen Perhubungan (2006) tentang Kajian Percepatan Pembangunan Infrastruktur Transportasi Melalui Kerjasama Pemerintah dan Swasta, sedikitnya terdapat 5 (lima) aspek yang dapat dijadikan tolak ukur keberhasilan KPS, yaitu: kebijakan, sumber daya, karakteristik pelaku, komunikasi, dan kecenderungan lembaga pelaksana.

Menurut Laurent dan Eny (2013) keberhasilan pelaksanaan KPS di Indonesia membutuhkan kajian komersial dan finansial. Financial term yang tersedia diharuskan memberikan ijin kepada investor untuk dapat menghasilkan return atau keuntungan dari investasinya dalam jumlah dan waktu yang wajar. Pelaksana (key actor) dan kerangka kelembagaan KPS dalam penyediaan infrastruktur dapat dilihat pada gambar 1.2

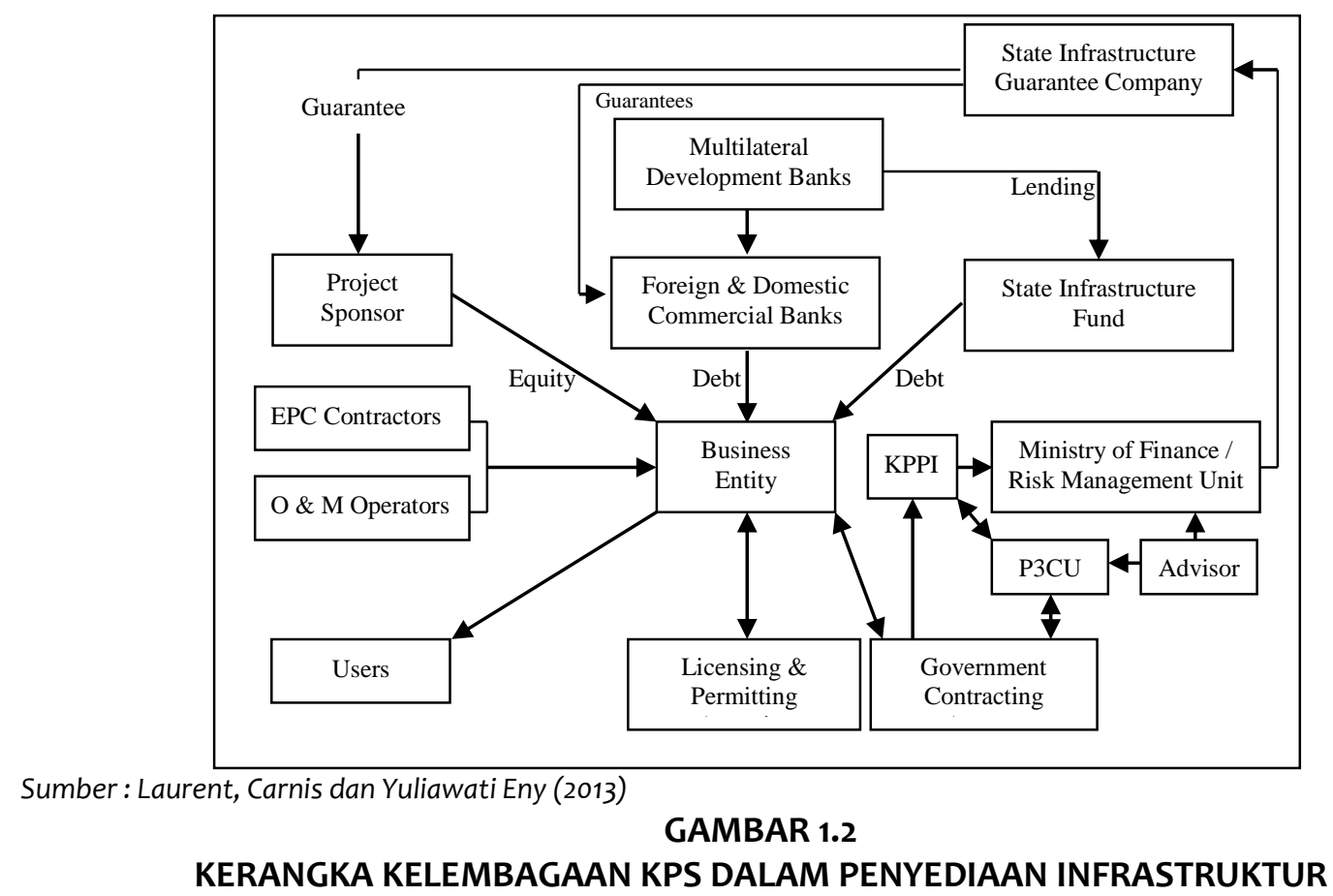

\section{ANALISIS IMPLEMENTASI KERJASAMA PEMERINTAH SWASTA DALAM PENYEDIAAN INFRASTRUKTUR DI PELABUHAN TANJUNG EMAS SEMARANG}

Penelitian mengenai KPS dalam penyediaan infrastruktur pelabuhan didasari oleh kebutuhan atas ketersediaan sarana prasarana penunjang aktivitas pelabuhan yang memadai dan mampu mendukung peningkatan kinerja operasional pelabuhan. Pembangunan dan pengembangan infrastruktur pelabuhan memerlukan pembiayaan investasi dengan nilai yang sangat besar. Salah satu program pemerintah dalam hal penguatan infrastruktur yang dapat diterapkan adalah KPS.

\section{Analisis karakteristik KPS dalam penyediaan infrastruktur pelabuhan Kepemilikan aset}

KPS merupakan kerjasama yang saling menguntungkan antara pemerintah, swasta dan masyarakat. Aset yang dimiliki akan tetap menjadi aset pemerintah. Hak Pengelolaan Lahan (HPL) Pelabuhan Tanjung Emas Semarang berada dibawah salah satu perusahaan BUMN yaitu PT. Pelabuhan Indonesia III (Persero) sejak tahun 1982. Sebelum pemberlakuan UU Nomor 17 
Aryani | Kajian Peluang Kerjasama Pemerintah Swasta (Kps) Dalam Penyediaan Infrastruktur Di Pelabuhan Tanjung

Emas Semarang

JPWK 11 (4)

Tahun 2008 tentang Pelayaran, PT. Pelindo III (Persero) Cabang Tanjung Emas Semarang memiliki wewenang sebagai penyelenggara pelabuhan dan sekaligus sebagai operator pelabuhan.

Pemberlakuan UU Nomor 17 Tahun 2008 tentang Pelayaran telah memberikan peran penting dalam penyelenggaraan kegiatan pelabuhan karena dengan adanya peraturan tersebut berarti pemerintah telah memberikan dasar untuk transformasi radikal dalam sistem nasional tata kelola pelabuhan yang dapat menyebabkan perbaikan efisiensi yang besar dalam jangka waktu menengah sampai dengan panjang. Undang-undang tersebut secara otomatis menghilangkan sistem monopoli atas kegiatan yang diselenggarakan pelabuhan Tanjung Emas Semarang. Dengan demikian membuka peluang kepada pihak lain sektor tersebut untuk peran serta operator lain, termasuk sektor swasta. Gambar dibawah ini secara sederhana memberikan pemetaan struktur tata kelola sistem pelabuhan komersial Tanjung Emas Semarang menurut UU Nomor 17 Tahun 2008 tentang Pelayaran.

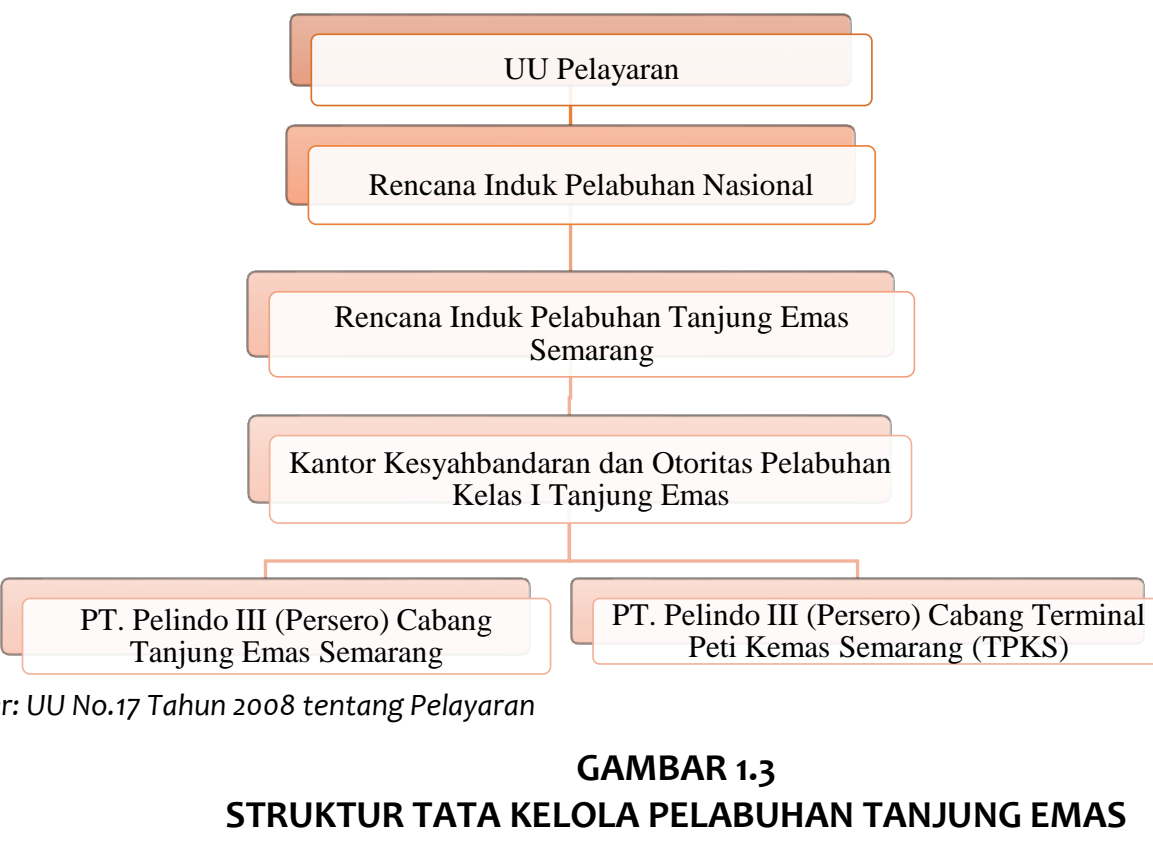

Terkait perubahan tata kelola tersebut, saat ini masih dilakukan pendataan kepemilikan aset yang berada di kawasan pelabuhan Tanjung Emas Semarang.

\section{Investasi Modal}

Investasi modal atau modalitas dalam penyediaan infrastruktur sangat tergantung dengan sumber pendanaan/pembiayaan. Di Indonesia, sumber pendanaan/pembiayaan terkait penyediaan infrastruktur dapat berasal dari berbagai pihak, antara lain: pihak pemerintah dalam hal ini untuk pemerintah pusat menggunakan APBN dan atau APBD untuk pemerintah daerah, Kerjasama Pemerintah Swasta (KPS), dana perusahaan BUMN dan juga dana perusahaan swasta. Modalitas penyediaan infrastruktur berdasarkan sumber pembiayaan dapat dilihat pada gambar dibawah ini : 


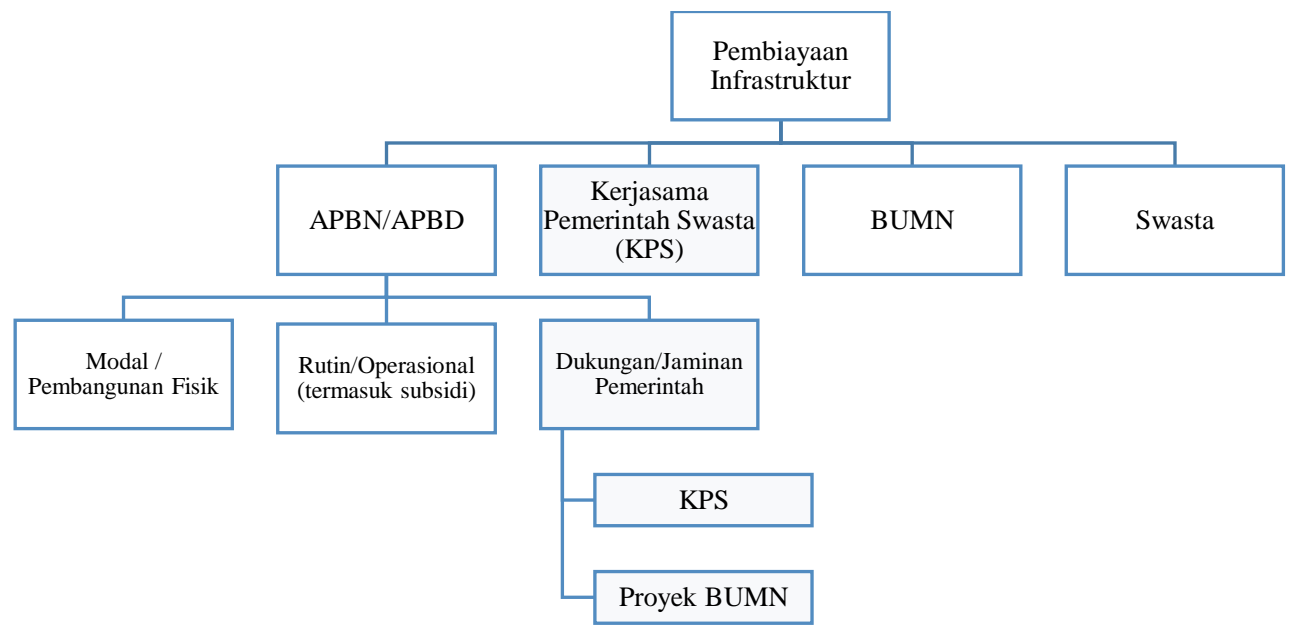

Sumber: Sarana Multi Infrastruktur (Persero), 2014

\section{GAMBAR 1.4 \\ MODALITAS PENGADAAN DALAM PEMBANGUNAN INFRASTRUKTUR}

\section{Resiko}

Resiko-resiko di dalam penyediaan infrastruktur dapat ditanggung oleh satu pihak ataupun ditanggung bersama oleh beberapa pihak tergantung dari nature resiko dan kemampuan masing-masing pihak dalam menyerap resiko tersebut. Alokasi resiko yang tidak terbatas pada liability dan profit masing-masing pihak yang terkait dalam KPS tersebut dibagi berdasarkan kesepakatan yang telah tercantum dalam perjanjian.

Aturan yang biasanya digunakan dalam pengalokasiaan resiko adalah sebagai berikut:

a. pemilik modal menanggung resiko yang terkait dengan keuangan dan kebijakan

b. penyedia pinjaman, menanggung resiko yang terkait dengan penyediaan pinjaman (seperti resiko suku bunga)

c. pemerintah, menanggung resiko yang terkait dengan kebijakan

\section{Bentuk dan Jangka Waktu Pelaksanaan KPS}

KPS dilaksanakan secara terstruktur dengan tujuan untuk mengoptimalkan nilai-nilai manfaat bagi publik, dan sekaligus dapat menarik minat investasi pihak swasta. KPS dalam penyediaan infrastruktur pelabuhan dapat memanfaatkan segala bentuk kerjasama pemerintah dan swasta. Pemilihan bentuk-bentuk kerjasama pada umumnya dilakukan berdasarkan hasil tinjauan resiko dan analisis menggunakan metode value for money. Pemilihan bentuk kerjasama pemerintah swasta dapat dilihat pada tabel dibawah ini:

TABEL 1.1

PEMILIHAN BENTUK KERJASAMA PEMERINTAH SWASTA

\begin{tabular}{|l|l|l|l|l|l|}
\hline & \multicolumn{1}{|c|}{$\begin{array}{c}\text { Service } \\
\text { contract }\end{array}$} & $\begin{array}{l}\text { Management } \\
\text { contract }\end{array}$ & Lease contract & $\begin{array}{c}\text { BOT/ } \\
\text { BOO/BTO }\end{array}$ & $\begin{array}{c}\text { Concession } \\
\text { contract }\end{array}$ \\
\hline Obyek & $\begin{array}{l}\text { Pengembangan, } \\
\text { bersifat terbatas, } \\
\text { operasional dan } \\
\text { pemeliharaan } \\
\text { tertentu }\end{array}$ & $\begin{array}{l}\text { Perbaikan, } \\
\text { operasional } \\
\text { dan } \\
\text { pemeliharaan }\end{array}$ & $\begin{array}{l}\text { Pengembangan, } \\
\text { operasional dan } \\
\text { pemeliharaan }\end{array}$ & $\begin{array}{l}\text { Mobilisasi } \\
\text { modal dari } \\
\text { pihak } \\
\text { swasta }\end{array}$ & $\begin{array}{l}\text { Perbaikan, } \\
\text { pengembanga } \\
\text { n, operasional } \\
\text { dan } \\
\text { pemeliharaan }\end{array}$ \\
\hline
\end{tabular}


Aryani | Kajian Peluang Kerjasama Pemerintah Swasta (Kps) Dalam Penyediaan Infrastruktur Di Pelabuhan Tanjung Emas Semarang

\begin{tabular}{|l|l|l|l|l|l|}
\hline $\begin{array}{l}\text { Kepemilikan } \\
\text { aset }\end{array}$ & Pemerintah & Pemerintah & Pemerintah & $\begin{array}{l}\text { Swasta } \\
\text { kemudian } \\
\text { diserahkan } \\
\text { pemerintah }\end{array}$ & $\begin{array}{l}\text { Swasta } \\
\text { kemudian } \\
\text { pemerahkan } \\
\text { pemah }\end{array}$ \\
\hline $\begin{array}{l}\text { Operasional \& } \\
\text { Pemeliharaan }\end{array}$ & $\begin{array}{l}\text { Pemerintah \& } \\
\text { Swasta }\end{array}$ & Swasta & Swasta & Swasta & Swasta \\
\hline Modal Investasi & Pemerintah & Pemerintah & Pemerintah & Swasta & Swasta \\
\hline Resiko & Pemerintah & Pemerintah & $\begin{array}{l}\text { Gabungan } \\
\text { (pemerintah \& } \\
\text { Swasta) }\end{array}$ & Swasta & Swasta \\
\hline Jangka waktu & $1-2$ tahun & $3-5$ tahun & $8-15$ tahun & $\begin{array}{l}20 \\
\text { tahun }\end{array}$ & 20 - 30 tahun \\
\hline Keuntungan & lumpsum & $\begin{array}{l}\text { Tambahan } \\
\text { biaya }\end{array}$ & Bagian dari tarif & Tarif & Tarif konsesi \\
\hline
\end{tabular}

Sumber: Grimsey, Darrin and Mervyn K. Lewis. 2004

Sedangkan prasyarat yang harus dipenuhi dalam pemilihan bentuk kerjasama pemerintah swasta dapat dilihat pada tabel dibawah ini:

TABEL 1.2

PRASYARAT PEMILIHAN BENTUK KPS

\begin{tabular}{|c|c|c|c|c|c|}
\hline & $\begin{array}{l}\text { Service } \\
\text { contract }\end{array}$ & $\begin{array}{c}\text { Management } \\
\text { contract }\end{array}$ & $\begin{array}{l}\text { Lease } \\
\text { contract }\end{array}$ & $\begin{array}{c}\text { BOT/ } \\
\text { BOO/BTO }\end{array}$ & $\begin{array}{c}\text { Concession } \\
\text { contract }\end{array}$ \\
\hline $\begin{array}{l}\text { Dukungan stakeholders } \\
\text { \& komitmen politik }\end{array}$ & Rendah & $\begin{array}{l}\text { Rendah / } \\
\text { menengah }\end{array}$ & Menengah & $\begin{array}{l}\text { Menengah / } \\
\text { tinggi }\end{array}$ & Tinggi \\
\hline $\begin{array}{l}\text { Tarif sebagai cost- } \\
\text { recovery }\end{array}$ & $\begin{array}{l}\text { Tidak } \\
\text { perlu }\end{array}$ & $\begin{array}{c}\text { Dianjurkan } \\
\text { (jangka panjang) }\end{array}$ & Perlu & Dianjurkan & Perlu \\
\hline Sistem informasi & Terbatas & Cukup & Perlu & Perlu & Perlu \\
\hline $\begin{array}{l}\text { Pengembangan } \\
\text { struktur pengaturan }\end{array}$ & Minimal & Minimal / sedang & $\begin{array}{l}\text { Sangat } \\
\text { perlu }\end{array}$ & $\begin{array}{l}\text { Sangat } \\
\text { perlu }\end{array}$ & Sangat perlu \\
\hline $\begin{array}{l}\text { Good country financial } \\
\text { rating }\end{array}$ & $\begin{array}{l}\text { Tidak } \\
\text { perlu }\end{array}$ & Tidak perlu & Perlu & Perlu & Perlu \\
\hline
\end{tabular}

Sumber: Grimsey, Darrin and Mervyn K. Lewis. 2004

Sejak diberlakukannya UU Pelayaran maka pengelolaan pelabuhan dilakukan secara professional oleh BUP berdasarkan UU No. 17 Tahun 2008, PP No. 61 Tahun 2009, PP No. 5 Tahun 2010 dan PP No. 20 Tahun 2010. Terkait pemberlakukan peraturan-peraturan tersebut maka dimungkinkan dalam penyelenggaraan pelabuhan digunakan konsep multioperator. Multioperator tersebut dapat berupa BUMN, BUMD, Badan Hukum Indonesia, maupun perorangan yang memenuhi persyaratan menjadi Badan Usaha Pelabuhan. 
Dengan sistem tata kelola pelabuhan yang ada saat ini, pemerintah akan menerapkan model umum administrasi pelabuhan yang dikenal dengan 'pelabuhan sistem sewa'. Melalui model ini, pemerintah dalam hal ini otoritas pelabuhan akan mengusahakan tersedianya fasilitas pelabuhan, mengatur akses menuju pelabuhan dan mempersiapkan fasilitas dasar pelabuhan seperti alur pelayaran, pemecah ombak dan alat-alat navigasi. Dan di sisi lain, operator pelabuhan akan menyewa sarana fasilitas yang telah disediakan otoritas pelabuhan tersebut, dan kemudian memberikan layanan pelabuhan berdasarkan kontrak jangka panjang atau konsesi. Bentuk konsesi atau bentuk lain perjanjian dalam penyelenggaraan pelabuhan dapat digambarkan sebagai berikut:

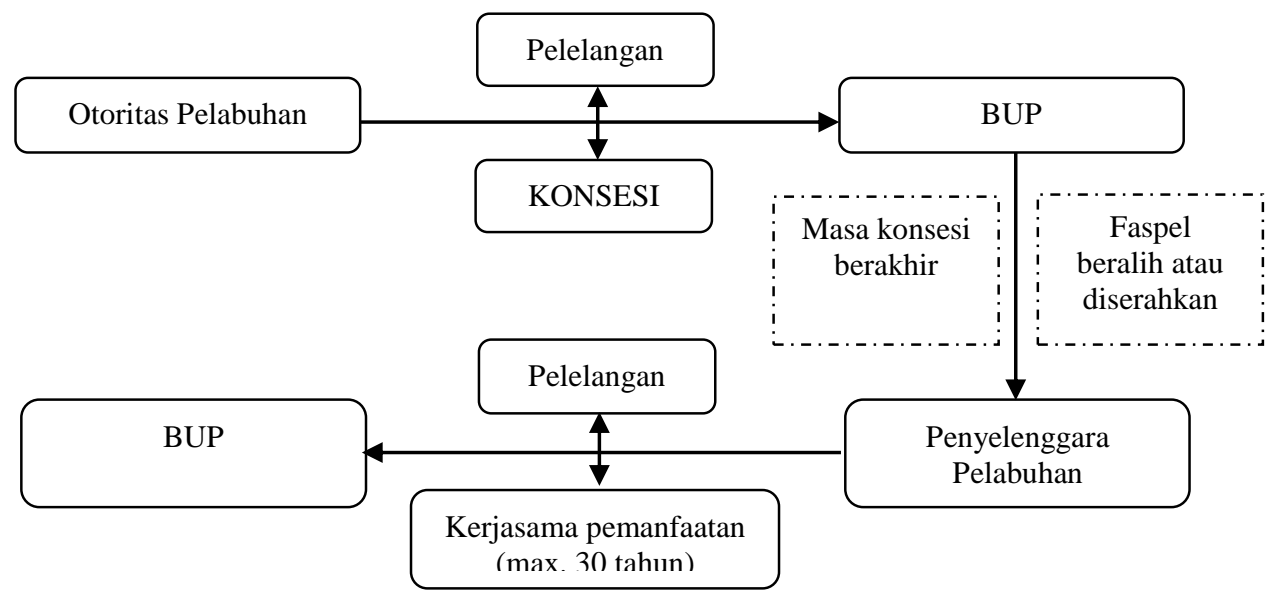

Sumber : Direktorat Jenderal Perhubungan Laut Direktorat Pelabuhan dan Pengerukan, 2010

\section{GAMBAR 1.5 \\ MEKANISME PELAKSANAAN KONSESI INFRASTRUKTUR PELABUHAN}

Penetapan konsesi infrastruktur pelabuhan dapat dilaksanakan melalui mekanisme pelelangan apabila BUP yang ada bukan dari perusahaan BUMN, sedangkan untuk penetapan konsesi terhadap BUMN dapat dilakukan dengan penunjukan langsung, pelelangan terbuka dengan preferensi serta pelelangan terbuka tanpa preferensi.

\section{Analisis potensi pelaksanaan KPS}

Penyediaan infrastruktur dalam rangka pengembangan dan pembangunan pelabuhan Tanjung Emas Semarang dilaksanakan dengan berdasar pada Rencana Induk Pelabuhan yang ditetapkan dengan Peraturan Menteri Perhubungan Nomor PM. 18 Tahun 2013, meliputi pembangunan dan pengembangan kawasan pelabuhan Tanjung Emas dengan areal daratan seluas 963,925 Ha dan areal perairan seluas $17.800 \mathrm{Ha}$.

Berdasarkan Rencana Induk yang disiapkan pemerintah tersebut, Pelabuhan Tanjung Emas Semarang direncanakan memiliki 10 (sepuluh) kawasan atau zona pemanfaatan ruang wilayah daratan, meliputi:

a. Zona 1 yaitu kawasan general cargo, merupakan kawasan yang disediakan untuk melakukan kegiatan bongkar muat untuk barang cargo sepeti komoditas pertanian, perkebunan, maupun industri olahan.

b. Zona Il yaitu kawasan industri penunjang kepelabuhanan. Kawasan ini adalah kawasan yang diperuntukkan untuk industri penunjang pelabuhan.

c. Zona III yaitu kawasan petikemas (container zone) merupakan kawasan dimana terdapat lapangan terbuka dan gudang tertutup untuk penumpukan barang dalam container. 
Aryani | Kajian Peluang Kerjasama Pemerintah Swasta (Kps) Dalam Penyediaan Infrastruktur Di Pelabuhan Tanjung Emas Semarang

d. Zona IV yaitu kawasan terminal penumpang yang dikhususkan untuk angkutan penumpang dan penunjang kegiatan embakasi dan debarkasi penumpang kapal laut.

e. Zona $\mathrm{V}$ yaitu kawasan muatan curah yang merupakan kawasan yang digunakan untuk kegiatan muat-bongkar barang-barang curah, baik curah kering maupun curah cair.

f. Zona VI yaitu kawasan pembangunan dan perbaikan kapal (docking) merupakan kawasan yang digunakan sebagai tempat relokasi dan pengembangan kegiatan pembangunan dan perbaikan kapal (docking).

g. Zona VII yaitu kawasan perkantoran, kawasan ini merupakan tempat yang diperuntukan untuk keperluan operasional pelabuhan maupun perkantoran pelayanan jasa kepelabuhanan.

h. Zona VIII yaitu kawasan logistik yang merupakan kawasan yang dikhususkan untuk kegiatan-kegiatan konsolidasi dan distribusi barang.

i. Zona IX yaitu kawasan pelabuhan rakyat yang merupakan kawasan khusus untuk kegiatan pelayaran rakyat, yang mencakup aktivitas muat-bongkar antar pulau

j. Zona X yaitu kawasan fasilitas pelabuhan lainnya. Kawasan ini meliputi fasilitas-fasilitas yang diperlukan yang lokasinya tersebar di areal pelabuhan.

Pemanfaatan ruang wilayah daratan pada pelabuhan Tanjung Emas Semarang terkait pengembangan dan pembangunan infrastruktur pelabuhan dapat dilihat pada gambar dibawah ini:

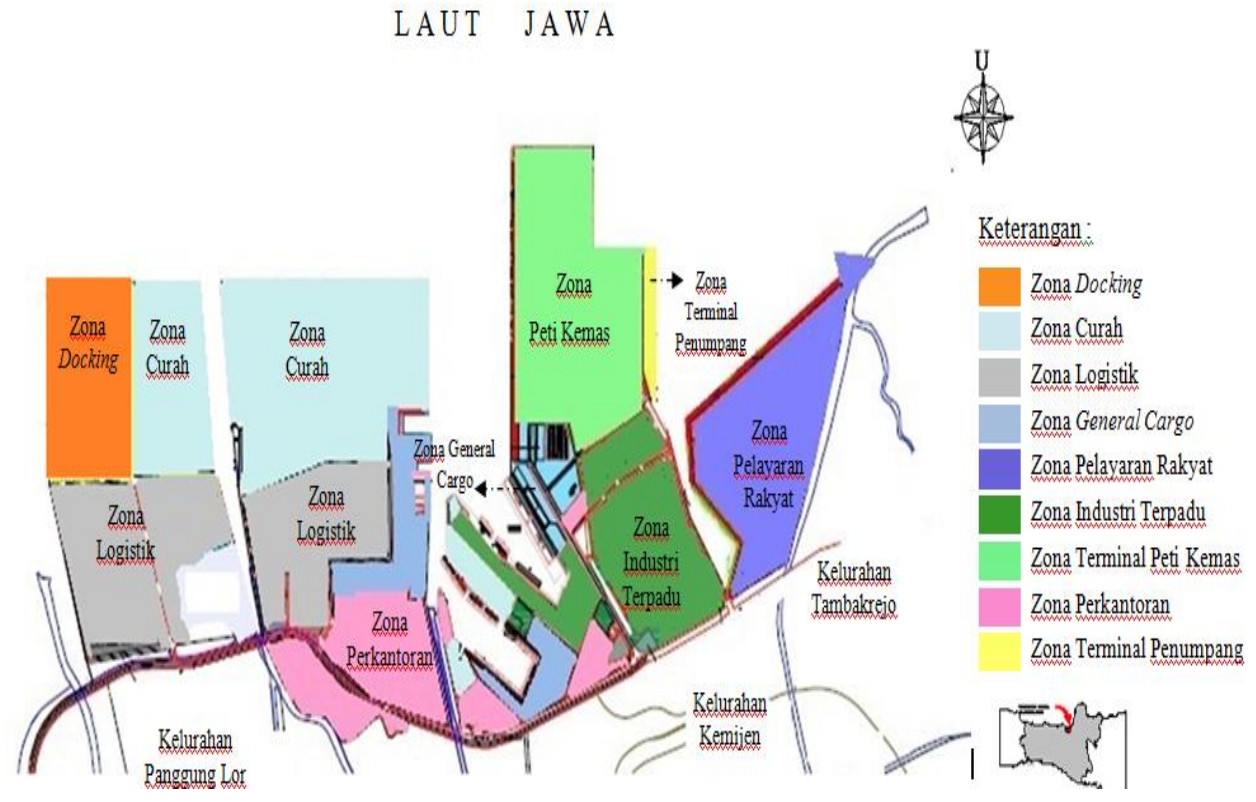

Sumber: Kantor Kesyahbandaran dan Otoritas Pelabuhan Kelas I Tanjung Emas, 2013

GAMBAR 1.6

RENCANA PEMANFAATAN RUANG PELABUHAN TANJUNG EMAS SEMARANG

Rencana pengembangan tersebut membutuhkan biaya yang sangat besar, prioritas pengembangan pelabuhan pada secara keseluruhan diperkirakan membutuhkan biaya 7 Trilliun Rupiah, yang pelaksanaannya direncanakan selama 3 tahap. Secara khusus PT. Pelindo III (Persero) cabang TPKS Semarang melakukan pengembangan terminal peti kemas sesuai Rencana Induk Pelabuhan Tanjung Emas Semarang yaitu dengan pembangunan container yard (CY-05) seluas 5,3 hektar, perpanjangan dermaga sepanjang 105 meter, dan penambahan alat 
sebanyak 11 (sebelas) unit serta reaktivasi jalur rel kereta api sebagai sarana prasarana angkutan peti kemas melalui multimoda transportasi. Biaya yang dibutuhkan oleh TPKS dalam melaksanakan pengembangan sarana dan prasarana penunjang kegiatan muat bongkar di terminal peti kemas (container) sesuai dengan Rencana Induk Pelabuhan adalah sebesar $900 \mathrm{M}$ (Sembilan Ratus Milyar). Besarnya pembiayaan yang dibutuhkan dalam pengembangan pelabuhan Tanjung Emas merupakan salah satu potensi pelaksanaan KPS. Pelaksanaan KPS memiliki tujuan untuk mengurangi beban pemerintah dalam penyediaan anggaran terkait pembangunan dan pengembangan infrastruktur.

\section{Analisis kendala pelaksanaan KPS}

Perubahan tata kelola pelabuhan Tanjung Emas mengakibatkan perubahan wewenang pihakpihak penyelenggara pelabuhan. Pendataan aset atas kawasan pelabuhan Tanjung Emas menjadi kendala dalam pelaksanaan KPS. Aset dalam kawasan TPKS saat ini masih berada di bawah pengelolaan BUP yakni PT. Pelindo III (Persero), sehingga dalam penyediaan infrastruktur di TPKS masih dilakukan oleh BUP.

Pelaksanaan KPS dalam penyediaan infrastrukur pelabuhan Tanjung Emas Semarang melibatkan kebijakan dan peraturan instansi-instansi pemerintah serta pihak-pihak swasta di lingkungan pelabuhan. Banyaknya institusi yang terkait dengan penyelenggaraan kegiatan di pelabuhan mengakibatkan sistem pelayanan yang tidak teratur. Selain banyaknya institusi yang terlibat dalam kegiatan yang ada di Pelabuhan Tanjung Emas Semarang, pemahaman dan kesiapan SDM penyelenggara, pengelola dan pemangku kebijakan dalam penyelenggaraan kegiatan kepelabuhanan terkait skema KPS masih sangat kurang.

Kepemilikan aset yang masih dalam pendataan, kurangnya pemahaman pihak penyelenggara kegiatan pelabuhan, stakeholder, dan masyarakat tentang skema KPS, kurangnya sosialisasi aturan dan kebijakan serta kurangnya SDM yang berkompeten untuk melaksanakan KPS, menyebabkan pihak-pihak penyelenggara kegiatan pelabuhan di Tanjung Emas tidak menerapkan skema KPS dalam penyediaan infrastruktur yang dibutuhkan.

\section{Analisis persepsi pelaksana KPS}

Kementerian Perhubungan Direktorat Jenderal Perhubungan Laut sebagai pihak pemerintah berpendapat bahwa penyediaan infrastruktur melalui skema KPS akan sangat memberikan pengaruh positif, karena dengan melalui skema KPS pembiayaan dalam penyediaan infrastruktur akan dapat terpenuhi dengan efektif dan efisien. Sedangkan menurut KSOP Kelas I Pelabuhan Tanjung Emas Semarang berpendapat bahwa pelaksanaan KPS akan menimbulkan dampak positif terhadap penyelenggaraan kegiatan di pelabuhan, pelaksanaan KPS akan menghindari terjadinya monopoli terhadap penyelenggaraan kegiatan pelabuhan oleh satu pihak tertentu, membuka peluang masuknya BUP untuk menjadi operator penyelenggara kegiatan di pelabuhan Tanjung Emas Semarang.

Sedangkan pendapat PT. Pelindo III (Persero) sebagai operator kegiatan di pelabuhan Tanjung Emas, sangat optimis mampu menyediakan infrastruktur pelabuhan, baik infrastruktur pokok maupun infrastruktur penunjang kegiatan pelabuhan. PT. Pelindo III (Persero) Cabang TPKS berpendapat bahwa penyediaan infrastruktur pelabuhan khususnya kawasan terminal peti kemas akan memerlukan biaya yang sangat besar, namun apabila proses penyediaan infrastruktur tersebut melalui skema KPS akan memerlukan proses dan waktu yang sangat lama. Sehingga pihak TPKS tidak melakukan skema KPS dalam penyediaan infrastruktur pelabuhan dan sangat optimis dengan hasil operasional TPKS dapat mencukupi kebutuhan penyediaan infrastruktur di pelabuhan Tanjung Emas Semarang. 
Aryani | Kajian Peluang Kerjasama Pemerintah Swasta (Kps) Dalam Penyediaan Infrastruktur Di Pelabuhan Tanjung

Sebagian besar kawasan di pelabuhan Tanjung Emas berada dibawah kewenangan PT. Pelindo III (Persero). Namun demikian terkait dengan RIP Pelabuhan Tanjung Emas yang ada saat ini, terdapat satu kawasan area yang berada di luar daerah operasional PT. Pelindo III (Persero), sehingga membuka peluang untuk dilaksanakannya KPS dalam penyediaan infrastruktur pada kawasan tersebut. Kawasan yang dimaksud adalah kawasan logistik.

Untuk lebih jelasnya dapat dilihat pada gambar berikut :

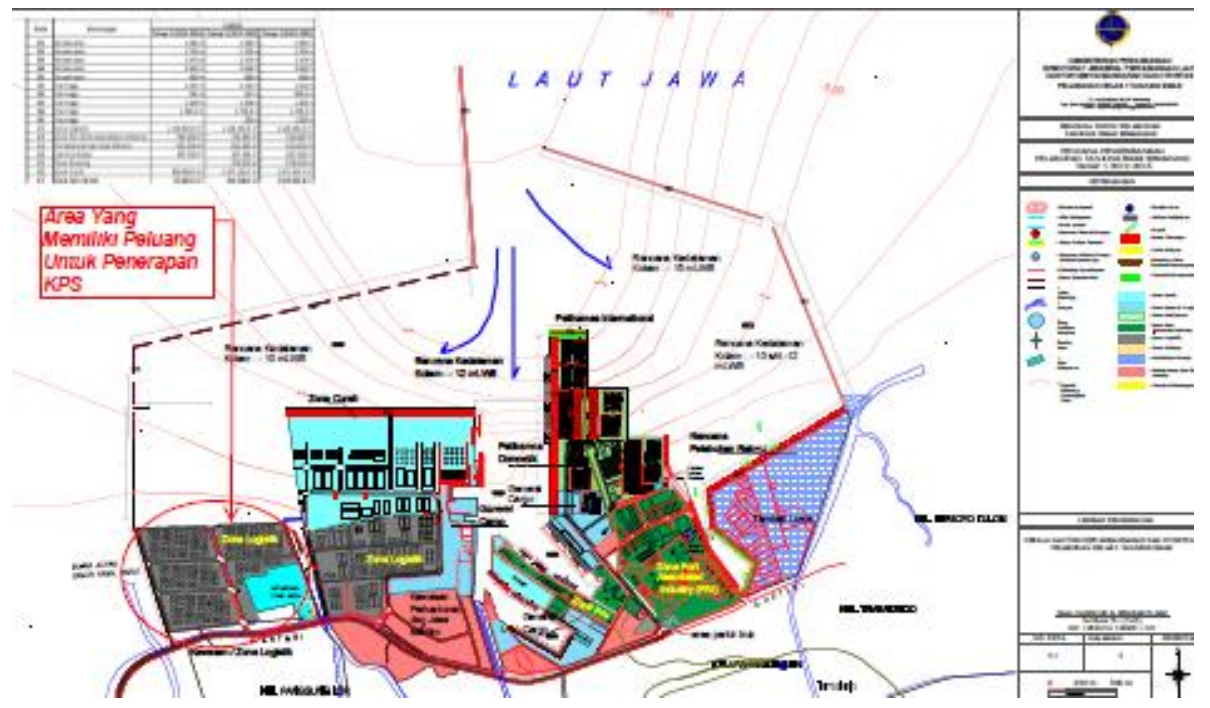

Sumber: Kantor Kesyahbandaran dan Otoritas Pelabuhan Kelas I Tanjung Emas, 2013

\section{GAMBAR 1.7 \\ KAWASAN YANG BERPELUANG MELAKSANAKAN KPS DI PELABUHAN TANJUNG EMAS SEMARANG}

\section{Analisis kebijakan kelembagaan dalam pelaksanaan KPS}

Kebijakan pelaksanaan kerjasama pemerintah dan swasta terdiri atas peraturan yang terkait secara langsung dengan KPS dan peraturan yang secara tidak langsung terkait dengan pelaksanaan KPS. Peraturan yang terkait secara langsung dengan pelaksanaan KPS, antara lain: Peraturan Presiden Nomor 38/2015 tentang Kerjasama Pemerintah Dengan Badan Usaha Dalam Penyediaan Infrastruktur, Perpres 42/2005 tentang Komite Kebijakan Percepatan Penyediaan Infrastruktur (KKPPI), Peraturan Menteri Keuangan Nomor 38/PMK.01/2006 tentang Petunjuk Pelaksanaan Pengendalian Dan Pengelolaan Resiko Atas Penyediaan Infrastruktur, Peraturan Menteri Koordinator Bidang Perekonomian Nomor 3/2006 tentang Tata Cara Evaluasi Proyek Kerjasama Pemerintah Dengan Badan Usaha Dalam Penyediaan Infrastruktur Yang Membutuhkan Dukungan Pemerintah.

\section{Sintesa Kajian KPS Dalam Penyediaan Infrastruktur di Pelabuhan Tanjung Emas}

Kerjasama Pemerintah Swasta (KPS) dalam penyediaan infrastruktur telah diatur sesuai dengan Peraturan Presiden Nomor 38 Tahun 2015 tentang Kerjasama Pemerintah Dengan Badan Usaha Dalam Penyediaan Infrastruktur terdapat rincian infrastruktur ekonomi dan infrastruktur sosial, yang salah satunya adalah infrastruktur transportasi. 
TABEL 1.3

\section{KAJIAN KERJASAMA PEMERINTAH SWASTA (KPS) DALAM PENYEDIAAN INFRASTRUKTUR DI PELABUHAN TANJUNG EMAS SEMARANG}

\begin{tabular}{|c|c|c|}
\hline No. & Kajian & Keterangan \\
\hline \multirow[t]{5}{*}{1.} & \multicolumn{2}{|c|}{ Karakteristik KPS dalam penyediaan infrastruktur pelabuhan, antara lain: } \\
\hline & 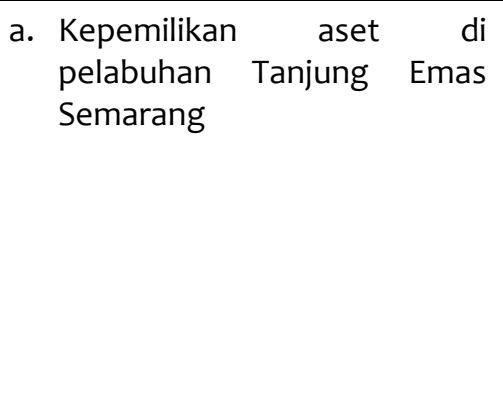 & $\begin{array}{l}\text { - Sejak tahun 1982, hak Pengelolaan Lahan berada } \\
\text { dibawah PT. Pelindo III (Persero) } \\
\text { - Implementasi UU No. 17/2008 tentang pelayaran, } \\
\text { menyebabkan terjadinya perubahan tata kelola } \\
\text { pelabuhan Tanjung Emas Semarang } \\
\text { - PT. Pelindo III (Persero) hanya memiliki wewenang } \\
\text { sebagai operator penyelenggara kegiatan pelabuhan, } \\
\text { terkait hal tersebut pendataan dan peralihan aset yang } \\
\text { ada saat ini masih dilakukan. }\end{array}$ \\
\hline & \multirow[t]{3}{*}{ b. Investasi modal } & $\begin{array}{l}\text { - Modalitas dalam penyediaan infrastruktur bergantung } \\
\text { dari sumber pembiayaan, seperti APBN/APBD, KPS, dana } \\
\text { BUMN, maupun dana perusahaan swasta }\end{array}$ \\
\hline & & $\begin{array}{l}\text { - Terkait pengembangan pelabuhan Tanjung Emas } \\
\text { Semarang terdapat } 2 \text { (dua) sumber pembiayaan, yaitu: } \\
\text { 1) APBN digunakan untuk pembiayaan infrastruktur } \\
\text { wilayah perairan (alur dan pemecah ombak) }\end{array}$ \\
\hline & & $\begin{array}{l}\text { 2) Dana BUMN digunakan untuk pembiayaan } \\
\text { infrastruktur wilayah daratan, seperti dermaga, } \\
\text { sarana bongkar muat dan fasilitas penunjang }\end{array}$ \\
\hline & c. Resiko & $\begin{array}{l}\text { - Resiko dalam penyediaan infrastruktur dapat } \\
\text { ditanggung oleh satu pihak maupun ditanggung } \\
\text { bersama oleh beberapa pihak tergantung dari } \\
\text { kemampuan masing-masing pihak dalam menyerap } \\
\text { resiko } \\
\text { - Resiko yang dapat terjadi dalam pelaksanaan KPS adalah } \\
\text { resiko negara dan resiko politik. Kondisi negara yang } \\
\text { cenderung positif dan kondisi politik yang stabil dapat } \\
\text { memberikan jaminan dan asuransi dalam menangani } \\
\text { suatu resiko kerjasama }\end{array}$ \\
\hline & d. Bentuk Kerjasama & $\begin{array}{l}\text { - Perubahan tata kelola pelabuhan menyebabkan } \\
\text { pemerintah (otoritas pelabuhan) menerapkan } \\
\text { "pelabuhan sistem sewa". } \\
\text { - Otoritas pelabuhan mempersiapkan fasilitas, } \\
\text { infrastruktur dasar seperti alur pelayaran, pemecah } \\
\text { ombak dan alat navigasi, serta aksesibilitas menuju } \\
\text { pelabuhan. } \\
\text { - Pihak operator pelabuhan (BUP) akan menyewa fasilitas } \\
\text { yang telah disediakan otoritas pelabuhan tersebut, dan } \\
\text { kemudian memberikan layanan pelabuhan berdasarkan } \\
\text { kontrak jangka panjang atau konsesi. }\end{array}$ \\
\hline \multirow[t]{2}{*}{2.} & \multicolumn{2}{|c|}{ Potensi dan kendala pelaksanaan KPS dalam penyediaan infrastruktur pelabuhan } \\
\hline & a. Potensi pelaksanaan KPS & $\begin{array}{l}\text { - Pelaksanaan KPS melibatkan beberapa sektor, antara } \\
\text { lain pemerintah, swasta dan komunitas masyarakat. }\end{array}$ \\
\hline
\end{tabular}




\begin{tabular}{|c|c|c|}
\hline & & $\begin{array}{l}\text { - Keberhasilan KPS pada pembangunan infrastruktur erat } \\
\text { kaitannya dengan peningkatan efisiensi, inovasi, serta } \\
\text { penciptaan nilai manfaat (value for money) } \\
\text { - Pembangunan dan pengembangan pelabuhan Tanjung } \\
\text { Emas membutuhkan pembiayaan yang besar merupakan } \\
\text { latar belakang pelaksanaan KPS. } \\
\text { - Melalui KPS pembiayaan melalui beban APBN/APBD } \\
\text { dapat dikurangi atau bahkan dihilangkan dengan adanya } \\
\text { investor atau pihak swasta yang menyediakan sumber } \\
\text { pembiayaan }\end{array}$ \\
\hline & b. Kendala pelaksanaan KPS & $\begin{array}{l}\text { - Perubahan tata kelola pelabuhan berdasarkan UU } \\
\text { No.17/2008 menyebabkan perubahan wewenang pihak- } \\
\text { pihak penyelenggara pelabuhan. } \\
\text { - Pendataan aset pada kawasan pelabuhan menjadi } \\
\text { kendala dalam pelaksanaan KPS } \\
\text { - Kurangnya pemahaman pihak penyelenggara kegiatan } \\
\text { pelabuhan, dan stakeholder terkait skema KPS } \\
\text { - Kurangnya sosialisasi aturan dan kebijakan, serta } \\
\text { kurangnya SDM yang tersedia menyebabkan pihak-pihak } \\
\text { penyelenggara kegiatan pelabuhan di pelabuhan } \\
\text { Tanjung Emas tidak menerapkan skema KPS dalam } \\
\text { penyediaan infrastruktur yang dibutuhkan }\end{array}$ \\
\hline 3. & $\begin{array}{lc}\text { Persepsi } & \text { pemerintah } \\
\text { stakeholder pelaksana KPS } & \end{array}$ & $\begin{array}{l}\text { - Instansi pemerintah terdiri atas penyelenggara } \\
\text { pelabuhan yakni Otoritas Pelabuhan serta beberapa } \\
\text { instansi pemerintah yang terkait kegiatan } \\
\text { kepelabuhanan seperti kesehatan pelabuhan, bea cukai, } \\
\text { imigrasi dan kekarantinaan } \\
\text { - Otoritas pelabuhan merupakan lembaga pemerintah di } \\
\text { pelabuhan yang memiliki wewenang sebagai otoritas } \\
\text { untuk melaksanakan fungsi pengaturan, pengendalian, } \\
\text { dan pengawasan kegiatan kepelabuhanan yang } \\
\text { diusahakan secara komersial } \\
\text { - Stakeholder dalam penelitian ini adalah Badan Usaha } \\
\text { Pelabuhan (BUP) yang memiliki wewenang dalam } \\
\text { pengoperasian terminal dan fasilitas yang tersedia di } \\
\text { pelabuhan Tanjung Emas. BUP Tanjung Emas Semarang } \\
\text { adalah PT. Pelabuhan Indonesia III (Persero) Cabang } \\
\text { Tanjung Emas dan Cabang TPKS }\end{array}$ \\
\hline & a. Persepsi Pemerintah & $\begin{array}{l}\text { - Pemerintah pusat dalam hal ini adalah Direktorat } \\
\text { Jenderal Perhubungan Laut - Direktorat Pelabuhan dan } \\
\text { Pengerukan, Kementerian Perhubungan, memiliki } \\
\text { beberapa pendapat terkait pembangunan dan } \\
\text { pengembangan Pelabuhan Tanjung Emas, antara lain: } \\
\checkmark \text { Kecenderungan dalam penyediaan infrastruktur } \\
\text { pelabuhan melalui KPS akan sangat memberikan } \\
\text { dampak positif, karena dengan skema pembiayaan } \\
\text { KPS, infrastruktur pelabuhan dapat terpenuhi dengan } \\
\text { efektif dan efisien } \\
\checkmark \text { Ketersediaan dan kesiapan SDM sebagai } \\
\text { penyelenggara pelabuhan sangat dibutuhkan untuk } \\
\text { menunjang peningkatan kinerja pelabuhan }\end{array}$ \\
\hline
\end{tabular}




\begin{tabular}{|c|c|c|}
\hline & & $\begin{array}{l}\checkmark \text { Peraturan dan kebijakan sebagai dasar hukum dalam } \\
\text { pelaksanaan KPS dalam penyediaan infrastruktur } \\
\text { pelabuhan belum ditentukan pemerintah, sehingga } \\
\text { pihak-pihak tidak mengetahui dan memahami skema } \\
\text { pelaksanaan KPS } \\
\text { - Kantor Kesyahbandaran dan Otoritas Pelabuhan } \\
\text { Tanjung Emas Kelas } 1 \text { sebagai otoritas pelabuhan di } \\
\text { Tanjung Emas memiliki pendapat bahwa pelaksanaan } \\
\text { KPS akan menimbulkan dampak positif karena } \\
\text { pelaksanaan KPS akan menghindari terjadinya monopoli } \\
\text { terhadap penyelenggaraan kegiatan pelabuhan, } \\
\text { membuka peluang masuknya BUP, sehingga } \\
\text { menimbulkan persaingan menuju kualitas yang lebih } \\
\text { baik }\end{array}$ \\
\hline & $\begin{array}{l}\text { b. Persepsi BUP Tanjung Emas } \\
\text { Cabang TPKS }\end{array}$ & $\begin{array}{l}\text { - PT. Pelindo III (Persero) Cabang TPKS merupakan } \\
\text { operator pelabuhan yang melakukan pengaturan, } \\
\text { pengendalian, dan pengawasan kegiatan } \\
\text { kepelabuhanan yang ada di terminal peti kemas } \\
\text { - Sebagai operator kegiatan di pelabuhan Tanjung Emas } \\
\text { PT. Pelindo III (Persero) sangat optimis mampu } \\
\text { menyediakan infrastruktur pelabuhan, baik infrastruktur } \\
\text { pokok maupun infrastruktur penunjang } \\
\text { - PT. Pelindo III (Persero) Cabang TPKS berpendapat } \\
\text { bahwa penyediaan infrastruktur pelabuhan khususnya } \\
\text { kawasan terminal peti kemas akan memerlukan biaya } \\
\text { yang sangat besar, namun apabila proses penyediaan } \\
\text { infrastruktur tersebut dilakukan melalui skema KPS akan } \\
\text { memerlukan proses dan waktu yang sangat lama } \\
\text { - Pihak TPKS tidak melakukan skema KPS dalam } \\
\text { penyediaan infrastruktur pelabuhan dan sangat optimis } \\
\text { dengan hasil operasional TPKS mampu mencukupi } \\
\text { kebutuhan penyediaan infrastruktur di kawasan TPKS } \\
\text { Tanjung Emas Semarang }\end{array}$ \\
\hline 4. & \multicolumn{2}{|c|}{ Kebijakan Kelembagaan terkait pelaksanaan KPS dalam penyediaan infrastruktur } \\
\hline & a. Peraturan Lintas Sektor & $\begin{array}{l}\text { - Peraturan Presiden Nomor 38/2015 tentang Kerjasama } \\
\text { Badan Usaha Dalam Penyediaan Infrastruktur } \\
\text { - Perpres Nomor 42/2005 tentang Komite Kebijakan } \\
\text { Percepatan Penyediaan Infrastruktur (KKPPI) } \\
\text { - Peraturan Menteri Keuangan Nomor 38/PMK.01/2006 } \\
\text { tentang Petunjuk Pelaksanaan Pengendalian dan } \\
\text { Pengelolaan Resiko Atas Penyediaan Infrastruktur } \\
\text { - Peraturan Menteri Koordinator Bidang Perekonomian } \\
\text { Nomor 3/2006 tentang Tata Cara Evaluasi Proyek } \\
\text { Kerjasama Pemerintah Dengan Badan Usaha Dalam } \\
\text { Penyediaan Infrastruktur Yang Membutuhkan } \\
\text { Dukungan Pemerintah }\end{array}$ \\
\hline & b. Peraturan Sektor terkait & $\begin{array}{l}\text { Undang-Undang Nomor } 17 \text { Tahun } 2008 \text { tentang pelayaran. } \\
\checkmark \text { UU Pelayaran merupakan dasar untuk reformasi } \\
\text { sistem penyelenggaraan pelabuhan di Indonesia. } \\
\checkmark \text { Hal mendasar yang terjadi setelah implementasi UU } \\
\text { pelayaran tersebut adalah adanya upaya pemerintah } \\
\text { dalam menghapus monopoli atas sektor pelabuhan }\end{array}$ \\
\hline
\end{tabular}




\begin{tabular}{|l|l|}
\hline & $\begin{array}{l}\text { dan membuka kesempatan bagi partisipasi sektor } \\
\text { swasta. } \\
\checkmark \text { Meskipun demikian, hingga saat ini belum terdapat } \\
\text { kebijakan yang dapat dijadikan sebagai dasar hukum } \\
\text { atas bentuk KPS dalam penyediaan infrastruktur } \\
\text { pelabuhan. }\end{array}$ \\
\hline
\end{tabular}

Sumber: Hasil analisis, 2015

\section{KESIMPULAN}

KPS merupakan salah satu program pemerintah dalam hal penyediaan melalui pembangunan dan/atau, pengembangan, serta pemeliharaan infrastruktur. KPS dalam penyediaan infrastruktur diatur dengan Peraturan Presiden Nomor 38 Tahun 2015 tentang Kerjasama Pemerintah Dengan Badan Usaha Dalam Penyediaan Infrastruktur. Keberhasilan KPS bergantung kepada bagaimana setiap pihak yang terkait dalam pelaksanaan KPS tersebut dapat memberikan dukungan sejak masa persiapan, pelaksanaan, dan pengawasan proyek yang operasional. Pemerintah sebagai penanggungjawab atas suatu proyek memiliki peran yang besar dalam menentukan arah kebijakan serta regulasi yang mendukung skema KPS.

Pengelolaan KPS yang efektif terdiri atas:

a. Institusi, kerangka hukum dan regulasi yang kuat

b. Standarisasi model KPS dengan nilai yang terukur dan jelas

c. Kapasitas dan efektifitas institusi pemerintah.

Pengembangan dan pembangunan pelabuhan Tanjung Emas dilaksanakan berdasar Keputusan Menteri Perhubungan PM. 18 Tahun 2013 tentang Rencana Induk Pelabuhan Tanjung Emas Semarang. Pembangunan dan pengembangan kawasan pelabuhan Tanjung Emas yang tercantum di dalam master plan meliputi areal daratan seluas 963,925 Ha dan areal perairan seluas $17.800 \mathrm{Ha}$. Khusus pembangunan dan pengembangan kawasan Terminal Peti Kemas Semarang (TPKS), PT. Pelindo III (Persero) melakukan pembangunan container yard (CY-05) seluas 5,3 Ha, perpanjangan dermaga container sepanjang 105 meter dan reaktivasi jalur kereta api sebagai sarana angkutan peti kemas melalui multimoda transportasi.

Pembiayaan yang dibutuhkan terkait pembangunan dan pengembangan TPKS sangat besar, yang hingga saat ini berasal dari dana perusahaan PT.Pelindo III (Persero) yang diperoleh dari dana pinjaman bank dunia (world bank). Besarnya pembiayaan dalam penyediaan infrastruktur tersebut dapat diatasi dengan skema KPS.

Namun pelaksanaan KPS dalam penyediaan infrastruktur di Pelabuhan Tanjung Emas Semarang masih memiliki kendala-kendala sebagai berikut :

a. Banyaknya institusi yang terlibat dalam kegiatan di pelabuhan Tanjung Emas Semarang, menyebabkan kurangnya koordinasi dan tumpang tindih prosedur dan peraturan yang berlaku;

b. Tidak adanya sosialisasi terkait pelaksanaan KPS yang menyebabkan kurangnya pemahaman terhadap skema KPS;

c. Kurangnya SDM yang memiliki kompetensi yang sesuai dengan bidang keahliannya;

d. Proses pendataan aset yang belum selesai dilakukan, menyebabkan ketidakjelasan status masing-masing kawasan di Pelabuhan Tanjung Emas. 
Kendala-kendala tersebut diatas menjadi penyebab tidak dapat dilaksanakannya skema KPS dalam penyediaan infrastruktur di kawasan Terminal Peti Kemas. Namun demikian tidak menutup kemungkinan akan dapat dilaksanakan KPS pada kawasan yang tidak termasuk dalam daerah operasional PT.Pelindo III (Persero). Kawasan tersebut dalam Rencana Induk Pelabuhan, masih berada dibawah Pemerintah dan membuka kesempatan untuk Badan Usaha Pelabuhan yang memiliki kemampuan mengembangkan kawasan tersebut dengan menyediakan infrastruktur yang dibutuhkan dalam kawasan tersebut.

\section{DAFTAR PUSTAKA}

Berawi, Ali M dan Bambang Susantono. 2012. Perkembangan Kebijakan Pembiayaan Infrastruktur Transportasi Berbasis Kerjasama Pemerintah Swasta di Indonesia. Jurnal Transportasi Vol.12 No.2, hal.93-102

Bult-Spiering, WD and Dewulf, GPMR. 2006. Strategic Issues in Public-Private Partnerships: An International Perspective. Oxford: Blackwell Publishing, Ltd.

Grigg, Neil. 1988. Infrastructure Engineering and Management. John Willey\&Sons

Grimsey, Darrin and Mervyn K. Lewis. 2004. Public Private Partnerships. Cheltenham, UKNorthampton, MA, USA:Edward Elgar Publishing

Kodoatie, Robert J. 2005. Pengantar Manajemen Infrastruktur. Yogyakarta: Pustaka Pelajar

Koppenjan, J. 2008. "Public-Private Partnership and Mega-Projects". In Priemus, H Flyvbjerg, B and V. Wee (eds.). Decision-Making on Mega-Projects (pp. 189-213). Cheltenham: Edward Elgar Publishing.

Laurent, Carnis and Yuliawati Eny. 2013. Nusantara: Between Sky and Earth CouldTthe PPP be The Solution for Indonesian Airport Infrastructures?. Case Studies on Transport Policy. Vol.1 No.1, pages 18-26

Peraturan Menteri Perhubungan Nomor: PM. 18 Tahun 2013 tentang Rencana Induk Pelabuhan Tanjung Emas Semarang

Peraturan Presiden Republik Indonesia Nomor 38 Tahun 2015, tentang Kerjasama Pemerintah Dengan Badan Usaha Dalam Penyediaan Infrastruktur

Public Private Infrastructure Advisory Facility. 2003. Private Solutions for Infrastructure in Mexico. Washington DC: World Bank and Public-Private Infrastructure Advisory Facility (PPIAF)

Public Private Partnerships Kanada www.pppcouncil.ca di akses pada tanggal 10 Februari 2015

Pusat Kajian Strategis Pelayanan Jasa Perhubungan. 2006. Kajian Percepatan Pembangunan Infrastruktur Transportasi Melalui Kerjasama Pemerintah dan Swasta. Jakarta: Departemen Perhubungan

Saleh, D. Zahedy; M. Fikruzzaman Rahawin dan Tantiana Maria Cahyani. 2014. Mozaik Permasalahan Infrastruktur Indonesia. Depok: Ruas.

Sarana Multi Infrastruktur (Persero). 2014. Panduan Penyelenggaraan Kerjasama PemerintahSwasta (KPS) Dalam Penyediaan Infrastruktur. Jakarta: PT. Sarana Multi Infratsruktur (Persero)

The National Council For Public Private Partnerships (NCPPP) www.ncppp.org di akses pada tanggal 10 Februari 2015

Undang-Undang Republik Indonesia No. 17 Tahun 2008 tentang Pelayaran. Kementerian Perhubungan, Jakarta, 2008. 